Vot i ng behavi or i n I ndonesi a from 1999 to 2014 : rel i gi ous cl eavage or economi c perfor mance?

\begin{tabular}{|c|c|}
\hline 著者 & H gashi kat a Takayuki , Kawamur a Koi chi \\
\hline 権利 & $\begin{array}{l}\text { Copyr i ght s 日本貿易振興機構 (ジェトロ } \text { アジア } \\
\text { 経済研究所 / I nst i t ut e of Devel opi ng } \\
\text { Econom es, Japan Ext er nal Tr ade Organi zat i on } \\
\text { ( I DE- JETRO) ht t p: // www. i de. go.j p }\end{array}$ \\
\hline $\begin{array}{l}\text { j our nal or } \\
\text { publ i cat i on titl e }\end{array}$ & I DE Di scussi on Paper \\
\hline vol une & 512 \\
\hline year & 2015-03-01 \\
\hline URL & ht t p: //doi . or g/10. 20561/00037660 \\
\hline
\end{tabular}




\title{
INSTITUTE OF DEVELOPING ECONOMIES
}

IDE Discussion Papers are preliminary materials circulated

to stimulate discussions and critical comments

\section{IDE DISCUSSION PAPER No. 512}

\section{Voting Behavior in Indonesia from 1999 to 2014 \\ Religious Cleavage or Economic Performance?}

Takayuki HIGASHIKATA* $^{*}$ and Koichi KAWAMURA ${ }^{+}$

\section{March 2015}

\begin{abstract}
In this study, we examine the voting behavior in Indonesian parliamentary elections from 1999 to 2014. After summarizing the changes in Indonesian parties' share of the vote from a historical standpoint, we investigate the voting behavior with simple regression models to analyze the effect of regional characteristics on Islamic/secular parties' vote share, using aggregated panel data at the district level. Then, we also test the hypothesis of retrospective economic voting. The results show that districts which formerly stood strongly behind Islamic parties continued to select those parties, or gave preference to abstention over the parties in some elections. From the point of view of retrospective economic voting, we found that districts which experienced higher per capita economic growth gave more support to the ruling parties, although our results remain tentative because information on 2014 is not yet available.
\end{abstract}

Keywords: election, political party, voting behavior, electoral volatility, effective number of parties, religious cleavage voting, retrospective economic voting, Indonesia JEL classification: D72

\footnotetext{
* Researcher, Southeast Asian Studies Group I, Area Studies Center (takayuki_higashikata@ide.go.jp)

+ Researcher, Southeast Asian Studies Group I, Area Studies Center (koichi_kawamura@ide.go.jp)
} 
The Institute of Developing Economies (IDE) is a semigovernmental, nonpartisan, nonprofit research institute, founded in 1958. The Institute merged with the Japan External Trade Organization (JETRO) on July 1, 1998. The Institute conducts basic and comprehensive studies on economic and related affairs in all developing countries and regions, including Asia, the Middle East, Africa, Latin America, Oceania, and Eastern Europe.

The views expressed in this publication are those of the author(s). Publication does not imply endorsement by the Institute of Developing Economies of any of the views expressed within.

\section{INSTITUTE OF DEVELOPING ECONOMIES (IDE), JETRO}

\section{3-2-2, WAKABA, MIHAMA-KU, CHIBA-SHI}

\section{CHIBA 261-8545, JAPAN}

C2015 by Institute of Developing Economies, JETRO

No part of this publication may be reproduced without the prior permission of the IDE-JETRO. 


\title{
Voting Behavior in Indonesia from 1999 to 2014
}

\author{
Religious Cleavage or Economic Performance? \\ Takayuki Higashikata* and Koichi Kawamura ${ }^{+}$
}

\section{Abstract}

In this study, we examine the voting behavior in Indonesian parliamentary elections from 1999 to 2014. After summarizing the changes in Indonesian parties' share of the vote from a historical standpoint, we investigate the voting behavior with simple regression models to analyze the effect of regional characteristics on Islamic/secular parties' vote share, using aggregated panel data at the district level. Then, we also test the hypothesis of retrospective economic voting. The results show that districts which formerly stood strongly behind Islamic parties continued to select those parties, or gave preference to abstention over the parties in some elections. From the point of view of retrospective economic voting, we found that districts which experienced higher per capita economic growth gave more support to the ruling parties, although our results remain tentative because information on 2014 is not yet available.

Keywords: election, political party, voting behavior, electoral volatility, effective number of parties, religious cleavage voting, retrospective economic voting, Indonesia JEL classification: D72

\footnotetext{
* Researcher, Southeast Asian Studies Group I, Area Studies Center (takayuki_higashikata@ide.go.jp) ${ }^{+}$Researcher, Southeast Asian Studies Group I, Area Studies Center (koichi_kawamura@ide.go.jp) This paper is a background paper for "The 2014 General Election (in Japanese)" in a two-year project of Institute of Developing Economies (IDE), "2014 Elections of Indonesia: 10-year Yudhoyono Presidency in Retrospect, a New President in Prospect." We are grateful to participants for their comments and suggestions on a very preliminary version of this paper in a workshop "The Indonesian Elections 2014" at the Institute of Southeast Asian Studies (ISEAS) on October 31 ${ }^{\text {st }}, 2014$. Needless to say, all mistakes are our own.
} 


\section{Introduction}

After the fall of Soeharto's authoritarian regime, Indonesia experienced four general elections and three presidential elections between 1999 and 2014. All elections were held relatively fairly and peacefully, and both winners and losers accepted the final polling counts, resulting in peaceful power transitions. Because of its peaceful consecutive elections, Indonesia has been praised by the international community as an example of successful democratization as well as stability.

However, the steadiness of Indonesia's democratic regime does not mean that electoral results are stable. No party has ever won the first in a series of elections and acquired a majority in the House of People's Representatives (Dewan Perwakilan Rakyat: DPR). ${ }^{1}$ Because polling results fluctuated every time elections were held, the composition of the legislature has changed drastically.

If we look back at Indonesian politics under the parliamentary democracy of the 1950s, it used to be understood that political parties, whose constituents were split by socio-religious cleavages between secularism and Islam, competed against one another for political power. According to Feith (1957), such electoral divisions in the 1950s gave birth to the four major parties representing particular social strata. They were the secular nationalistic Indonesian National Party (Partai Nasional Indonesia: PNI), the traditional Islamic Nahdlatul Ulama (NU), the modern Islamic Masyumi, and the leftist Indonesian Communist Party (Partai Komunis Indonesia: PKI). The party system based on Indonesian socio-religious cleavages was defined as "aliran politics."

However, since the democratization in 1998, the Indonesian party system has

\footnotetext{
1 This paper focuses on the general elections of the House of People's Representative (DPR), the lower chamber, and it does not deal with those of the House of Local Representatives (Dewan Perwakilan Daerah: DPD), the upper chamber. Here, "the parliament" refers to the DPR unless specifically stated otherwise.
} 
never been fixed. Elections in the post-democratization period have been characterized by fluctuations and volatility. Such fluctuations in electoral results and the volatility of electoral behavior cannot be explained by the conventional view that support of parties by the electorate is based on traditional social cleavages. So, in this paper, we analyze whether religious cleavage, ${ }^{2}$ among other social cleavages, has any power to explain the voting behavior in Indonesia, and then we examine the cause of the fluctuations in the vote share.

The contributions of this paper are twofold. First, religious cleavage still strongly leads much of the electorate to consistently select the Islamic or secular parties. Second, we point out that retrospective economic voting has been observed in Indonesia as in other countries. ${ }^{3}$ Moreover, this may be one of the reasons why the vote share has fluctuated from time to time. Although certain events before elections, such as media coverage of the ruling party politicians' involvement in a corruption case, seem to be influential enough for the electorate to punish the ruling party, the electorate consistently looks at the regional economic condition they face; that is, if the regional economic condition is good, they tend to vote for the incumbent parties and vice versa.

This study is organized as follows. In section 1, we review the national trends in electoral results through analysis of electoral volatility and the effective number of parties; in section 2, we confirm the religious cleavage in Indonesia through simple statistical/quantitative analysis using regional (kabupaten/Kota) level data on the absolute

\footnotetext{
${ }^{2}$ In this paper we use the term religious cleavage in order to consider the differences of voting behavior between the devoted Muslim and the secular including the nominal Muslim and other religious minorities as pointed out by Esmer and Pettersson (2007). They emphasize the importance of analyzing the differences of voting behavior between the non-secular and the secular, rather than between different religions.

${ }^{3}$ Lewis-Beck and Stegmaier (2007) summarize literature on retrospective economic voting in developed countries. See, for example, Gélineau (2013) for an analysis on the economic voting in developing countries.
} 
voting share; in section 3 , we present the results of our analysis on retrospective economic voting. Then, the conclusion follows.

\section{National Trends: Analysis of relative voting share from 1999 to 2014}

In this section, we review the national trends in electoral results using the relative vote share of parties (parties' share of the valid vote). First, we define the term "Islamic parties," and then review the changes in ruling parties from a historical standpoint. Finally, we examine the degree of the electoral volatility and the effective number of parties in Indonesia to show that both the volatility and the number of parties remain high, while the level of the vote share among Islamic parties has not changed and block volatility between Islamic parties and secular ones was not so high. This implies that although Indonesian voters often change their choice of party at the time of election, most of them basically support another party of the same religious cleavage as the one for which they voted in the previous election.

\subsection{Islamic Parties in Indonesia}

We define Islamic parties as parties explicitly claiming Islam as the basis of their party platform or parties that claim to be national parties but whose main constituents are Islamic organizations. In the post-democratization period, for example, the United Development Party (Partai Persatuan Pembangunan: PPP) and the Justice and Prosperous Party (Partai Keadilan Sejahtera: PKS) explicitly claim that their party platform is based on Islam. On the other hand, the National Awakening Party (Partai Kebangkitan Bangsa: PKB) and the National Mandate Party (Partai Amanat Nasional: PAN) officially claim that their party platform is based on Pancasila, the official state 
philosophy defining religious equality, but in reality most of their cadres and constituents are from Nahdlatul Ulama (NU), the largest Muslim organization, and Muhammadiya, the second largest Muslim organization, respectively. ${ }^{4}$

LSI (2008b) justifies our argument that it is reasonable to regard the PKB and the PAN, which officially claim to be Pancasila parties, as Islamic parties. The survey revealed that respondents who were asked, "Which parties are Islamic parties?" chose the PPP (78\% of respondents), PKB (73\%), PAN (65\%), and PKS (57\%), while only about $30 \%$ of them answered the Golkar Party (Partai Golongan Karya), the Indonesian Democratic Party of Struggle (Partai Demokrasi Indonesia Perjuangan: PDIP), and the Democrat Party (Partai Demokrat) as Islamic parties. The same survey also showed that respondents who were questioned, "Which party is the most Islamic?" answered the PKS (20\% of respondents), PKB (18\%), PPP (13\%), and PAN (5\%). On the other hand, only $2 \%$ to $3 \%$ of respondents answered that the above four parties are the most Pancasilatic party, instead picking Golkar (16.5\%), PDIP (14\%), and the Democratic Party (8\%) as the most Pancasilatic parties. The survey results show that voters clearly differentiate between Islamic and secular parties and that they regard not only explicitly Islamic parties but also Islamic organization-based parties as Islamic parties.

\subsection{Ruling Parties from 1999 to 2014}

Table 1 reports that, since the democratization in 1998, the incumbent parties have never secured a position after elections. In the 1999 general elections, the PDIP led by independence leader Soekarno's daughter, Megawati Soekarnoputri, defeated the Soeharto-era ruling party, Golkar, with $33.7 \%$ of the votes.

\footnotetext{
${ }^{4}$ For a list of all Islamic parties participating in the post-democratization elections, see Table A1.
} 
$===$ Table $1==$

However, in the second democratic elections of 2004 where the PDIP suffered a crushing defeat and Golkar returned to the top position, most of the existing parties, including these two, received a lower share of votes. On the other hand, newly established parties such as the Democrat Party or parties which have no direct links with old parties such as the PKS gained in popularity.

In the next general elections of 2009, the Democrat Party won the first due to the high popularity of the incumbent President Susilo Bambang Yudhoyono. The other existing parties excluding the PKS received a lower share of votes again, while new parties that were established by strong presidential candidates, such as the Great Indonesia Movement Party (Partai Gerakan Indonesia Raya: Gerindra) led by the former Army Strategic Reserves (Kostrad) commander Prabowo Subianto, and the People's Conscience Party (Partai Hati Nurani Rakyat: Hanura) led by the former Indonesian National Armed Forces (TNI) commander Wiranto, successfully acquired parliamentary seats.

In the most recent general elections in 2014, when Yudhoyono ended his 10-year term just six months after the election, the ruling Democrat Party suffered heavy losses due to corruption charges against the party leaders. The PDIP regained the first winning party's position with $19 \%$ of the votes, but their vote share fell far short of their expectations. On the other hand, Gerindra made a great advance to become the third largest party, and the National Democrat Party (Partai NasDem), which split from Golkar, secured $6.7 \%$ of the vote share. 
As shown in these four election results, the top winning party has never been the same. The composition of parties below the second-place winning party has changed drastically as well, mainly because newly established parties successfully acquired voters' support at each election. Is this because "aliran politics" or traditional social cleavage was not effective anymore? Before answering this question, we discuss how electoral politics changed after democratization.

\subsection{Analysis of the National Level Data}

\subsubsection{Electoral Volatility and the Effective Number of Parties}

The drastic changes in electoral results after democratization can be measured by the rate of electoral volatility, or the net electoral change in the party vote between two consecutive elections (Bartolini and Mair 1990). ${ }^{5}$ Table 1 shows that the total electoral volatility in the 2004 general elections recorded 23.0, then increased to 28.7 in 2009 , and maintained its level in 2014 at 26.3.

These numbers can be called high if compared with those of other democracies. The mean electoral volatility of Indonesia, at 26, is more than three times higher than those of thirteen European democracies between 1885 and 1985 (Bartolini and Mair 1990), and more than two times higher than those of advanced industrial democracies today. It is comparable to the high electoral volatility of emerging democracies, i.e., 12.8 in Southern Europe, 22.8 in India, South Korea, and Taiwan, 28.4 in Sub-Sahara Africa, 30 in Latin America, and 44 in Eastern Europe (Hagopian 2007).

Responding to the high electoral volatility, a number of newly established

\footnotetext{
${ }^{5}$ Following Pedersen (1979), we define electoral volatility as a variable derived from summing the absolute values of all gains and all losses of political parties divided by two.
} 
political parties have competed in elections. "The new party boom" is not a mere temporal phenomenon of the post democratization period. Forty-eight parties competed in the 1999 general elections, and most of them, excluding Golkar and two other "official" opposition parties, the Indonesian Democratic Party (Partai Demokrasi Indonesia: PDI) ${ }^{6}$ and the PPP, were new parties. Out of 24 parties participating in the 2004 elections, 11 were new parties. In the 2009 general elections, newly established parties accounted for 14 out of 38 participating parties. However, there was only one new party participating in the 2014 elections since the requirements for participation in elections were modified to restrict new ones from joining the competition.

Those new parties not only participated in elections, but some of them successfully acquired parliamentary seats. The total number of parties that acquired parliamentary seats was 21 in 1999 and 16 in 2004 . The number decreased to nine in 2009 and 10 in 2014 since a parliamentary threshold was introduced to simplify the party system. It seems that the number of political parties has decreased since the 1999 general elections. However, if we look at the effective number of parties, ${ }^{7}$ the party system in Indonesia has been never simplified. As shown in Table 1, the electoral effective number of parties was 5.1 in 1999, 8.6 in 2004, 9.6 in 2009, and 8.9 in 2014. Thus, the effective number of parties at the electoral level gradually increased during the 10 years after democratization and still remained at a high level in 2014. Although the parliamentary threshold has been in place since 2009, the parliamentary effective number of parties has also continuously increased from 4.7 in 1999 to 7.1 in 2004, 6.1 in 2009, and 8.2 in 2014.

The introduction of the direct presidential elections in 2004 further pushed

\footnotetext{
${ }^{6}$ Later in October 1998, Megawati's faction divided the party to set up the PDIP.

7 According to Laakso and Taagepera (1979), the effective number of parties is defined as 1 divided by the sum of the squared decimal shares of the votes for each electoral party (electoral effective number) or seats won by each electoral party (parliamentary effective number).
} 
forward "the new party boom." The law on the presidential elections stipulates that a candidate who hopes to run in a presidential election has to be nominated by a party or a coalition of parties that have a certain share of parliamentary seats, that is, independent candidacy is prohibited. Thus, candidates who intend to run in a presidential election but have no strong support base in existing parties tend to establish their own parties. If their new parties succeed in securing enough votes to acquire parliamentary seats, they can have a chance to run in a presidential election. The first successful example of this was Yudhoyono's Democrat Party. Its success was imitated by Prabowo's Gerindra and Wiranto's Hanura, both of which acquired parliamentary seats just after their establishment.

\subsubsection{Party Identification Lost}

What caused such large electoral volatility in Indonesian electoral politics after democratization? It seems that the high electoral volatility and the new party boom after democratization were mainly caused by voters' loss of party identification.

Several opinion surveys have shown that a majority of voters do not identify themselves with any political party in Indonesia. LSI (2008a) revealed that the percentage of party identifiers in Indonesia decreased from $49 \%$ to $15 \%$ during the five years between 2003 and $2008 .^{8}$ A more recent survey shows that the percentage of party identifiers remained as low as 15\% on average during the three years from 2011 to 2014 (Indikator 2014). This figure is much lower than the mean percentage of party identifiers in emerging democracies, which is $34.7 \%$, not to mention in advanced industrial democracies, at $47.5 \%$. Rates of party identification in Indonesia are even lower than

\footnotetext{
${ }^{8}$ Party identification is measured by the percentage of those who answer positively to the question, "Do you feel close to any of the political parties?"
} 
those of Asian countries, where less than one-quarter of voters expresses an attachment to a party (Hagopian 2007). Due to this weak partisanship, a majority of voters tend to cast their votes for different parties at each election.

\subsubsection{The End of Cleavage Voting?}

How did voters without party identification decide which party to vote for? Although political parties can be still categorized into two camps, secular and Islamic, religious issues have not been the central electoral agenda in the last four elections. None of Islamic parties has pushed for Islamization of the state, including the introduction of Islamic law (sharia) at the national level. Since no other politically sensitive, socially divisive issues exist, parties never appeal to the electorate with clear stances on policy agendas. Therefore, neither party identification nor policy issues have affected voting behavior since 1999.

There has been an argument about whether aliran-style voting behavior can still be observed in parliamentary elections or not. Some literature argues that social cleavage cannot explain the voting behavior in the recent elections. Some researchers emphasize the effects of the socioeconomic modernization driven by high economic growth during the Soeharto era and the global revival of Islamic movements since the 1980s on electoral attitudes of voters. ${ }^{9}$

To examine whether religious cleavage voting, as used to be the case in "aliran politics," is still applicable to Indonesia's current elections, we first look at electoral volatility. As discussed above, the total scores of electoral volatility showed that voters'

\footnotetext{
${ }^{9}$ For example, see Basyaib and Abidin (1999), Haris (2004), Liddle and Mujani (2007), and Mujani and Liddle (2010). In contrast, others argue that the aliran politics framework is still applicable to current Indonesian electoral politics. See, for example, Lanti (2001), Suryadinata (2002), King (2003), Turmudi (2004), Ananta et al. (2004), and Baswedan (2004).
} 
behaviors have been unstable since democratization. However, if we look at the scores of block volatility between Islamic and secular voting to confirm the amount of swing votes from Islam to secular and vice versa, the block volatility was only 1.5 in the 2004 general elections, when the total volatility was as high as 23 , as shown in Table 1 . This means that $93.7 \%$ of voters swung only within Islamic or secular group. In 2009, when the total volatility increased to 26.6 , block volatility also increased to 9.2 , meaning $34.6 \%$ voted for parties belonging to another group. Although the 2009 results seemingly indicate the weakening of cleavage voting, block volatility in 2014 returned to as low as 2.0, and $92.5 \%$ of voters swung within each group. From these electoral volatility scores, Indonesian voters' behavior seems determined by the religious cleavage.

Of interest, on the other hand, is that the vote share of all Islamic parties, in fact, has not changed significantly in the post-democratization elections. Table 1 shows that the vote share of all 20 Islamic parties in 1999 was 37.6\%. In 2004, seven Islamic parties received $38.3 \%$ of votes. In 2009 , the vote share of nine Islamic parties decreased to $29.2 \%$, and in 2014 , the vote share of five Islamic parties maintained basically the same level, with $31.4 \%$. Thus, around $30 \%$ to $40 \%$ of the electorate constantly vote for any of the Islamic parties. This relatively constant share of votes received by Islamic parties shows a possible relevancy of voting behavior based on religious cleavage between secularism and Islam in the current elections.

In this section, we make analysis using the national-level information. It can be argued that voters distinguish between secular and Islamic parties, and the religious, or Islamic, voters prefer to vote for Islamic parties. Although voters do not identify with any particular party, their behavior is determined by religiosity. Therefore, even if the party for which they vote changes from one election to another, those who voted for any 
Islamic party in one election are likely to vote for some Islamic party at the next election. In the following section, we use district (kabupaten/kota) level data to test the hypothesis that religious cleavage influences voting behavior in Indonesia.

\section{Religious Cleavage}

We focus on analyzing the relative advantage of Islamic parties, especially in those districts where Islamic characteristics have been strongly observed. To measure the relative advantage of Islamic parties, we take the marginal vote share between the Islamic parties and the secular ones, that is, the Islamic parties' absolute vote share, minus that of the secular parties.

While in the above section we analyze the electoral results using relative voting share (the number of votes obtained over valid votes), hereafter we analyze voting behavior through absolute voting share, i.e., the number of votes obtained over the number of the electorate, at the district level in order to pay more attention to the share of abstention and invalid votes.

\subsection{Data and Summary Statistics}

Data on Indonesia's DPR election results and socioeconomic characteristics, aggregated by districts from 1999 to 2014, are used in this section and the next. In order to make a panel dataset, the districts' data are combined into 294 regional datasets on the basis of the 1996 administrative divisions because the district numbers have grown rapidly especially since the introduction of the decentralization law in $2001 .^{10}$

To measure the effects of regional Islamic characteristics on voting behavior,

\footnotetext{
${ }^{10}$ We have 497 districts for the 2014 DPR election data, 471 for the 2009 election, 440 for the 2004 election, and 311 for the 1999 election.
} 
we use the population share of Muslims which is derived from national population census results of 2000 and 2010 by BPS-Statistics Indonesia (BPS).

For the 2004 and 2014 elections, we use the numbers of mosques (Masjid) per 1,000 people at the district level from BPS's Potential of Village Data (Potensi Desa/Kelurahan: Podes). We regard this information as a kind of index of regional Muslim piety. During the past 15 years, Podes surveys were conducted five times, and data was made available for the years 1999, 2002, 2005, 2008, and 2011. So, we use the 1999 results of Podes for the analysis of the 1999 election, the 2002 results for the 2004 election, the 2008 results for the 2009 election, and the 2011 results for the latest election.

Unfortunately, mainly due to lack of information on the number of abstention and the electorate in some regions, especially in Bali Province and Nusa Tenggara Timur Province in the 2009 election, we have to discard some observations. So, we have 495 observations to use in the analysis of the elections in 1999 and 2009 as well as 1,070 observations from all the elections to analyze religious cleavage in Indonesia.

As shown in Table 2, the mean of the vote margin of Islamic parties was around $-25 \%$, and almost all (95\% of samples) could be observed between $19 \%$ and $-70 \%$ in the last four elections. During the 15 years, the number of Masjid per 1,000 people was around 1 on average, and 2.9 at most.

$===$ Table $2===$

\subsection{Comparison of Two Elections}

First, we compare the vote margin of Islamic parties in each election to see the trend of support for Islamic parties. In Figure 1, the vertical axis measures the Islamic 
parties' share minus the vote share of the secular parties in a DPR election, and the horizontal axis shows the same figures for the previous election five years before. If a district's vote margin was the same as five years before, the results of the election are depicted right on the 45 degree line. Figure 1 tells us that (1) vote margins of Islamic parties remained almost the same in the two elections because points are basically concentrated along the 45 degree line, (2) the level of Islamic parties' share was smaller than that of secular parties in most of the regions, and (3) some regions with a higher voting share received by Islamic parties in 2004 experienced a sharp drop in 2009 as points were below the 45 degree line.

$$
===\text { Figures } 1,2 \text { and } 3===
$$

Next, we turn to check the changes in vote share for Islamic and secular parties in the two elections. Figure 2 and Figure 3 show that the vote shares of Islamic parties fell dramatically in 2009 compared with the results in 2004 , while the vote shares of secular parties did not increase accordingly. The result indicates that the decrease in the vote shares of Islamic parties did not shift to cause an increase in vote shares of secular parties but possibly did cause an increase in abstention and/or invalid votes. To examine the relationship between vote shares of Islamic parties and the percentage of abstention/invalid votes, referred to hereinafter as Golput, ${ }^{11}$ we construct Figures 4 and 5.

\footnotetext{
${ }^{11}$ We could not obtain regional abstention vote numbers or invalid vote numbers for the 2004 elections from KPU. This is why we have not analyzed the share of abstention and that of invalid votes respectively here. Golput is an abbreviation for Golongan Putih, a group of people who abstain from voting or cast blank votes. It was originally used at the time of the 1971 general elections held under Soeharto's authoritarian regime when the anti-government movement led by student activists like Arief Budiman appealed to the people to abstain from elections or to cast a blank vote as a subtle expression of resistance against the government intervention in electoral process (Sanit 1992). Since then, Golput has implied voters' expression of distrust, dissatisfaction, or disobedience against the government,
} 
The two figures show that the amount of decrease in Islamic parties' vote shares from 2004 to 2009 was close to the increase in Golput shares (see Fig 4). On the other hand, the change in the secular parties' vote share during the period was not explained by the decrease in the Islamic parties' share, as shown in Fig 5.

$$
===\text { Figures } 4 \text { and } 5==
$$

Table 3 shows the relationship between vote shares of Islamic parties, secular parties and Golput. Districts are divided into five quantiles in accordance with the Islamic parties' vote shares in 2004 . The average vote share of Islamic parties in each quantile was from $15.2 \%$ in the first quantile, $23.5 \%$ in the second, $27.8 \%$ in the third, $33.4 \%$ in the fourth, and the $45.8 \%$ in the fifth. As reported in columns (2) and (4), the higher the vote share of Islamic parties in 2004 was, the larger the decrease of Islamic parties' share and the increase of Golput shares were from 2004 to 2009. On the other hand, the secular parties experienced a decline of their shares during the period, except for the fifth quantile which appears in column (6). These results seem to indicate that those who voted for Islamic parties in 2004 but stop supporting them in 2009 did not swing to secular parties but chose abstention (more precisely, Golput) under the assumption of no demographic change.

$===$ Table $3===$

ruling parties, or politics in general. The usage in this chapter, however, does not have the political connotation of the original wording and simply means those who abstain or cast blank or invalid votes at the time of election. 
How did those who abstained from the 2009 election behave in the 2014 election? From the lines for 2009-2014 in Table 3, we can point out that the vote shares of Islamic parties as well as of secular parties increased in 2014, meaning that some of those who chose Golput in 2009 returned to vote in 2014 . However, we have to note that vote shares of secular parties continued to increase in the regions of the fifth quantile, indicating the possibility that those who formerly voted for Islamic parties in 2004 swung to secular parties in 2014, especially in regions where support for Islamic parties was formerly strong.

\subsection{Vote Margin of Islamic Parties and Indicators of "Islamness"}

If religious cleavage exists, there is expected to be a positive correlation between vote margin and indicators of "Islamness" or Islamic piety. We would like to use the population share of Muslims and the number of Masjid per people as the indicators of Islamness.

$$
===\text { Figure } 6==
$$

Figure 6 plots the vote share margin of Islamic parties to secular ones against the population share of Muslims at the district level. The horizontal axis measures the odds ratio of the Muslims' share in logarithms. ${ }^{12}$ As is apparent from the figure, the

\footnotetext{
${ }^{12}$ We use the 2000 national population census data for the 1999 elections results and the 2010 national population census data for the 2009 election results. We also note that, while there were regions where population share of Muslims was below \% in the latest population census, Muslims consisted of $90 \%$ of the population in most districts ( 278 districts, or $55.9 \%$, in the 2010 population census). So, if we check the relation between the share of Muslims and the vote margin of Islamic-secular parties, it is difficult to see the correlation between them because almost half of the samples are scattered near the right-hand axis. Thus, here we use the logarithms of the odds ratio of the share of Muslims just for convenience.
} 
difference in the vote shares of Islamic parties and the secular ones were larger if regions had a higher population share of Muslims in 1999 and 2009. This implies that regions with a higher population share of Muslims had a tendency to support Islamic parties.

$===$ Figure 7 ==

We can confirm almost the same tendency in Figure 7 where the horizontal axis indicates the number of Masjid per 1000 people. The figure shows a positive correlation between the vote margin and the Masjid ratio. These two figures imply that the Islamic parties tend to have larger electoral support in regions where Islamic influences are strong if measured by the Muslim share and the Masjid ratio. So, next, we check the relation through simple regression models.

$===$ Table 4 ===

Table 4 summarizes the linear regression models using a panel dataset. It shows that the population share of Muslims and the number of mosques per 1,000 people have a positive correlation with the vote margin of Islamic parties. This means that the Islamic parties tend to receive relatively stronger support from the electorate in regions with stronger Islamic social influences measured by the Muslim share and the mosque ratio. This result supports the hypothesis that religious cleavage still exists in Indonesia in the sense of the existence of a statistically significant positive correlation between those Islamic variables and the vote margin of Islamic parties.

In sum, our analysis suggests that the vote share of Islamic parties has 
remained constant at both the national and regional levels during the past 15 years. Islamic parties tend to receive strong support from voters in areas where Islamic social influences are strong. Supporters of Islamic parties rarely swing to secular parties but instead choose to abstain. Thus, although electoral volatility increased after democratization and the introduction of presidential elections changed the dynamics of electoral politics, religious cleavage still influences to a great extent electoral behavior in Indonesia. Even if voters change the party they support, their choices do not cross the border between secular and Islamic parties. Instead, they shift their support within the same religious cleavage. We therefore conclude that the electoral division between secular and Islamic voters could explain basic Indonesian electoral behavior.

Our results seem to be consistent with Pepinsky et al. (2012). They argue that no advantage of Islamic parties over non-Islamic parties can be seen if the voters know the economic policy platforms of the parties. Indeed, there has been almost no election in which economic policies were the main campaign issues among the parties since the introduction of free and fair elections in 1999.

If the voters in Indonesia tend to choose a party from the same religious camp, that is, basically consistently choose from the Islamic parties or the secular parties, then we should look for another reason why the electoral volatility was high in Indonesia. In the next section, we will discuss retrospective economic voting in Indonesia as one of the factors which cause voters to change support within each group.

\section{Retrospective Economic Voting}

In this section, we test the hypothesis of retrospective economic voting in Indonesia. As illustrated in section 1, in three of the four elections, the ruling parties at the 
time of elections suffered a defeat, that is, the Golkar in 1999, the PDIP in 2004, and the Democrat Party in 2014. It is often explained that the Golkar's defeat was due to its responsibility for mismanaging the country's economy when it was hit by the Asian financial crisis in 1997/1998. The PDIP lost in 2004 mainly because the Megawati Administration was judged as having achieved little, especially in economic policy. During her administration, Indonesia experienced a growth rate of only $4.2 \%$ on average. ${ }^{13}$ On the other hand, the ruling Democrat Party suffered a defeat in 2014 even though that administration achieved relatively high performance in the realm of the economy. It is often pointed out that one of the reasons was the outgoing President Yudhoyono's inability to prevent his party cadres from engaging in corruption. The only exceptional case was observed in the 2009 general elections when the President Yudhoyono's ruling party won the first position. It seems that voters gave high marks in the election to his achievement of political stability and economic recovery. In the election, the Democrat Party became the first winning party to rise from fifth place in the previous election, while Golkar, which won first place in the previous election, slipped down to the second place.

From anecdotal explanations about these electoral changes, we can hypothesize that Indonesian voters' electoral behavior is affected by their assessment of the incumbent administration's policy achievements, as has been the case in other democratic countries.

\footnotetext{
${ }^{13}$ This growth rate is the yearly average growth rate from fourth quarter of 1999 to third quarter of 2004. So, correctly speaking, this figure must be described as the results of the Wahid and Megawati administrations.
} 


\subsection{Data}

To investigate the retrospective economic voting hypothesis, we employ a model with the vote margins of ruling parties to opposition parties at the time of general elections, i.e., the difference in vote shares between ruling parties ${ }^{14}$ and opposition parties, as the dependent variable and employ the growth rate of per capita of the gross regional domestic product (GRDP) as the independent variable. We include year dummies and regional dummies as control variables. ${ }^{15}$

The data we use here is basically the same as that used in the previous section. We assume that the positive change in economic conditions caused voters to give more support to the ruling parties, when controlling for other factors. In order to test our hypothesis, in this section's analysis, we use the exponential mean of per capita economic growth rate between the elections as the economic condition variable. ${ }^{16}$

We construct the per capita economic growth as follows. First, for the economic growth data, we calculate the exponential mean of the growth rate using GRDP without oil and gas. However, as of the end of 2014, the gross regional domestic product data for the year 2014 were not available. So, we utilize the growth rate between 2009 and 2012 as if the growth rate had not changed until 2014. If we compare the average national economic growth rate from 2009 to 2012 with that of 2009 to 2014 , the latter is lower than the former. This means that the estimation results to be tested for the effect on

${ }_{15}^{14}$ For a list of all ruling parties at the time of elections, see Table A2.

15 The basic regression model we employ is as follows:

$$
\frac{P_{i, t}^{R}}{E_{i, t}}-\frac{P_{i, t}^{o}}{E_{i, t}}=\alpha+\beta x_{i, t}+\text { year dumm } y_{t}+\text { regional dumm } y_{i}+\epsilon_{i, t}
$$

where i: district, t: year, $P^{R}$ : the number of votes for ruling parties at the time of election, $P^{O}$ : the number of votes for opposition parties, $E$ : the number of the electorate, $x$ : the growth rate of per capita GRDP (exponential mean of last five years), $\epsilon$ : error terms.

${ }_{16}$ Healy and Lenz (2014) pointed out that voting behavior of the electorate was affected most by the election-year economy because that information was more easily available ("end-heuristic").

However, we just take the 5-year (or 3-year) mean growth rate as the economic variable in this paper because the economic data for the year 2014 is not available at the time of this writing. 
2014 election could be underestimated. Second, we use the number of the electorate instead of the estimated population for each region to calculate the exponential mean of population growth rate because we think the growth rate of the number of the electorate reflected more precisely the real growth rate of the population between the elections. ${ }^{17}$ Due to this limitation, we must pay attention to the evaluation of the results later. Needless to say, our analysis remains a temporal one.

$===$ Table $5===$

Table 5 shows the summary statistics. In Sample 1, we use whole sample, while we excluded those samples that lack some information like an abstention record. In Sample 2, we did not include observations if the per capita GRDP growth rate were not within four standard deviation of the mean. ${ }^{18}$ When comparing Sample 1 with Sample 2, we find that samples such as districts with per capita economic growth of $46.8 \%$ and $-47.4 \%$ on average are not included any longer in Sample 2. The sample sizes are 840 and 833 respectively.

As shown in Table 5, the vote margin of the ruling parties declined gradually, from $12.8 \%$ to $6.2 \%$ in Sample 1, and from $13 \%$ to $6.2 \%$ in Sample 2. On the other hand, with the decline of the vote margin, the average growth rate of the per capita GRDP rose higher, from $-0.3 \%$ to $3.8 \%$ in Sample 1 , and from $0.1 \%$ to $3.8 \%$ in Sample 2. Thus, the simple correlation between the vote margin of the ruling parties and the growth rate of the

\footnotetext{
${ }^{17}$ In short, basically we calculate $\left(\ln Y_{i, t}-\ln Y_{i, t-5}\right) / 5-\left(\ln E_{i, t}-\ln E_{i, t-5}\right) / 5$, where Y is the GRDP without oil and gas, though for the year 2014, we calculate $\left(\ln Y_{i, 2012}-\ln Y_{i, 2009}\right) / 3-\left(\ln E_{i, 2014}-\right.$ $\left.\ln E_{i, 2009}\right) / 5$.

${ }^{18}$ Theoretically speaking, $99.9937 \%$ of the observations fall within four standard deviation of the mean.
} 
per capita GRDP seems to be negative.

\subsection{Tentative Results}

Table 6 shows the results of our estimation. All models, from (1) to (8), show that the increases in the growth rates of per capita GRDP are significantly associated with a larger difference between the ruling parties' share and the opposition parties' share. Figure 8 illustrates the relation using the results in (6) and (8).

$$
===\text { Table } 6 \text { and Figure } 8===
$$

First, if we limit the sample to only during the time of 2004 and 2009 elections, a 1 percentage increase in the per capita GRDP growth rate produces a 0.5 to 1.5 percentage-point increase in the ruling parties' share relative to the share of the opposition parties. If we include samples from the 2014 election, the coefficients decrease. They are almost the same, around 0.5, if in Sample 1, while they decrease more in Sample 2 as from 0.7 to 0.5 , and from 1.5 to 0.8 . This decrease of the coefficients must be partly caused by the variable we use. As we have already mentioned, the national average growth rate of GDP from 2009 to 2012 was $6.32 \%$, though the economic growth rate from 2009 to 2014 was $5.97 \%$. So, the results of our estimation including the sample of the 2014 election might be underestimated.

Next, if we check the coefficients of the year dummy of 2009 , the dummy variable indicates that ruling parties lost around 5 percentage points in vote share in the 2014 election when compared with opposition parties. In the summary statistics, we see

the 5 percentage-point decrease of the vote margin of ruling parties over opposition 
parties in 2014 when compared with the results of the 2009 election. According to our estimation, this decrease was explained as the result of a year-specific negative shock which was observed in all districts. We think that this is because of the negative public evaluation of the ruling parties, especially the Democrat Party, following a series of corruption cases that came to light in which the party executives including the chairperson were successively arrested. This negative evaluation of political performance caused the party to lose its share of the vote. It is pointed out, however, that the party's loss was much smaller than expected before the election. We argue that the moderate loss of the Democrat Party in 2014 can be partly explained by voters who positively evaluated the ruling parties' economic performance.

\section{Conclusion}

In this paper, we examine voting behavior in the DPR elections from 1999 to 2014. When Indonesia was democratized in 1998, there was an argument that the fierce party competition of the 1950 s would return and "aliran politics" would be revived in elections. After observing 15 years of electoral politics, we find that the argument is partly wrong and partly correct. Electoral volatility in the past 15 -year period is much more than is assumed. This may indicate that "aliran politics" has disappeared due to the drastic change in electoral politics since democratization. So, in order to analyze the continuity and change in Indonesia's electoral politics, we investigated the voting behavior with simple regression models and provide three results. First, we clarified that districts which formerly stood strongly behind Islamic parties continued to select those parties, or gave preference to abstention over the secular parties in the 2009 election. Second, we analyzed the effect of regional characteristics on the vote margin of Islamic 
parties, using aggregated panel data at the district level, and confirmed the positive correlations between them. Third, from the analysis of retrospective economic voting, we found that districts which experienced higher per capita economic growth gave more support to the ruling parties; a one-time shock in an election year, such as the negative evaluation of the Democrat Party in 2014, also had a large effect on the degree of support given to the ruling parties.

With these results, we conclude that religious cleavage still affects voting behavior in Indonesia in the sense that there is a statistically significant correlation between the regional religious character and the margin of the vote share of Islamic parties versus secular parties. This means that voters basically tend to choose the same camp as they did in the preceding elections, though retrospective economic voting caused them to decide which party to select within the camp.

Our analysis seems to be consistent with the argument that in the absence of strong party identities, voters decide their electoral choice on the basis of retrospective evaluations of government performance (Mainwaring and Torcal 2006). However, according to Hagopian (2007), electoral volatility will diminish with the continuity of economic growth, if voters are primarily retrospectively evaluating government performance. Contrary to this theoretical view, a diminishing trend in electoral volatility has not been confirmed in spite of the Yudhoyono government's higher economic growth during his 10-year term.

Finally, we should note that the results of our analysis about the retrospective economic voting on the 2014 election are still tentative. Further analysis must wait until the full dataset is available. 


\section{References}

Ananta, Aris, Evi Nurvidya Arifin, and Leo Suryadinata. Indonesian Electoral Behaviour: A Statistical Perspective. Singapore: Institute of Southeast Asian Studies, 2004.

Badan Pusat Statistik (BPS). Penduduk Indonesia: Hasil Sensus Penduduk Tahun 2000 [Indonesian population: The result of the 2000 Population Census]. Jakarta: Badan Pusat Statistik, 2001.

------. Produk Domestik Regional Bruto Kabupaten/Kota di Indonesia 1998-2001 [Gross regional domestic product of regencies/municipalities in Indonesia 1998-2001]. Jakarta: Badan Pusat Statistik, 2003.

-----. Produk Domestik Regional Bruto Kabupaten/Kota di Indonesia 2002-2006 [Gross regional domestic product of regencies/municipalities in Indonesia 2002-2006]. Jakarta: Badan Pusat Statistik, 2007.

-----. Penduduk Indonesia: Hasil Sensus Penduduk Tahun 2010 [Indonesian population: The result of the 2010 Population Census]. Jakarta: Badan Pusat Statistik, 2011.

------. Produk Domestik Regional Bruto Kabupaten/Kota di Indonesia 2008-2012 [Gross regional dmestic product of regencies/municipalities in Indonesia 2008-2012]. Jakarta: Badan Pusat Statistik, 2013.

Bartolini, Stefano and Peter Mair. Identity, Competition and Electoral Availability: The Stabilisation of European Electorates 1885-1985. Cambridge: Cambridge University Press, 1990.

Baswedan, Anies Rasyid. "Sirkulasi Suara dalam Pemilu 2004" [Circulation of votes in the 2004 general elections]. Analisis CSIS, 33(2), 2004: pp. 173-89.

Basyaib, Hamid, and Hamid Abidin, eds. Mengapa Partai Islam Kalah? Perjalanan Politik Islam dari Prapemilu '99 sampai Pemilihan Presiden [Why did Islamic parties loose?: Political journey of Islam from the pre-1999 election until presidential election]. Jakarta: Alvabet, 1999.

Converse, Philip E. “Of Time and Partisan Stability”. Comparative Political Studies, 2(2), 1969: pp. 139-171.

Esmer, Yilmaz, and Thorleif Pettersson. "The Effects of Religion and Religiosity on 
Voting Behavior". In The Oxford Handbook of Political Behavior, edited by

Russell J. Dalton and Hans-Dieter Klingemann, New York: Oxford University Press, 2007: pp. 481-503.

Feith, Herbert. The Indonesian Elections of 1955. Ithaca, NY: Southeast Asia Program, Cornell University, 1957.

Gélineau, François. "Electoral Accountability in the Developing World". Electoral Studies, 32, 2013: pp.418-424.

Hagopian, Frances. "Parties and Voters in Emerging Democracies". In The Oxford Handbook of Comparative Politics, edited by Carles Boix and Susan C. Stokes, New York: Oxford University Press, 2007: pp. 582-603.

Haris, Syamsuddin. "Politicization of Religion and the Failure of Islamic Parties in the 1999 General Election”. In Elections in Indonesia: The New Order and Beyond, edited by Hans Antlov and Sven Cederroth, London: Routledge, 2004: pp. 6176.

Healy, Andrew, and Gabriel S, Lenz. "Substituting the End for the Whole: Why Voters Respond Primarily to the Election-Year Economy". American Journal of Political Science, 58(1), 2014: pp.31-47.

Indikator. Efek Kampanye dan Efek Jokowi: Elektabilitas Partai Jelang Pemilu Legislatif 2014 [Effects of campaign and effects of Jokowi: Electability of parties toward 2014 legislative general election]. Jakarta: Indikator, 2014.

King, Dwight Y. Half-hearted Reform: Electoral Institutions and the Struggle for Democracy in Indonesia. Westport, CT: Praeger, 2003.

Laakso, M. and R. Taagepera. "Effective Number of Parties: A Measure with Application to West Europe”. Comparative Political Studies, 12(1), 1979: pp. 3-27.

Lanti, Irman. G. Back to the (Slightly Different) Future: Continuity and Change in Indonesian Politics. Singapore: Institute of Southeast Asian Studies, 2001.

Lembaga Survei Indonesia (LSI). Kecenderungan Swing Voter Menjelang Pemilu Legislatif 2009 [Trends of swing voters toward the 2009 legislative general election]. Jakarta: Lembaga Survei Indonesia, 2008a.

------. Kekuatan Elektoral Partai-Partai Islam Menjelang Pemilu 2009 [Electoral strength of Islamic parties toward the 2009 legislative election]. Jakarta: 
Lembaga Survei Indonesia, $2008 b$.

Lewis-Beck, Michael and Mary Stegmaier. "Economic Determinants of Electoral Outcomes". Annual Review of Political Science, 3, 2007: pp. 183-219.

Liddle, R. William and Saiful Mujani. "Leadership, Party, and Religion: Explaining Voting Behavior in Indonesia". Comparative Political Studies, 40(7), 2007: pp. 832-57.

Mainwaring, Scott, and M. Torcal. "Party System Institutionalization and Party System Theory after the Third Wave Democratization". In Handbook of Political Parties, edited by R.S. Katz and W. Crotty, London: Sage, 2006: pp. 204-227.

Mujani, Saiful and R. William Liddle. "Parsonalities, Parties, and Voters". Journal of Democracy, 21(2), 2010: pp. 35-49.

Pedersen, Mogens N. "The Dynamics of European Party Systems: Changing Patterns of Electoral Volatility". European Journal of Political Research, 7(1), 1979: pp. 126.

Pepinski, Thomas B., R. William Liddle, and Saiful Mujani. “Testing Islam’s Political Advantage: Evidence from Indonesia”. American Journal of Political Science, 56(3), 2012: pp.584-600.

Sanit, Arbi, ed. Golput: Analisa Pandangan Fenomena Politik [Golput: Philosophical analysis of political phenomena]. Jakarta: Sinar Harapan, 1992.

Suryadinata, Leo. Elections and Politics in Indonesia. Singapore: Institute of Southeast Asian Studies, 2002.

Turmudi, Endang. "Patronage, Aliran and Islamic Ideologies during elections in Jombang, East Java". In Elections in Indonesia: The New Order and Beyond, edited by Hans Antlov and Sven Cederroth, London: Routledge Curzon, 2004.

$===$ Tables A. 1 and A. $2===$ 
Figure 1. Vote Margin of Islamic Parties (1999-2014)

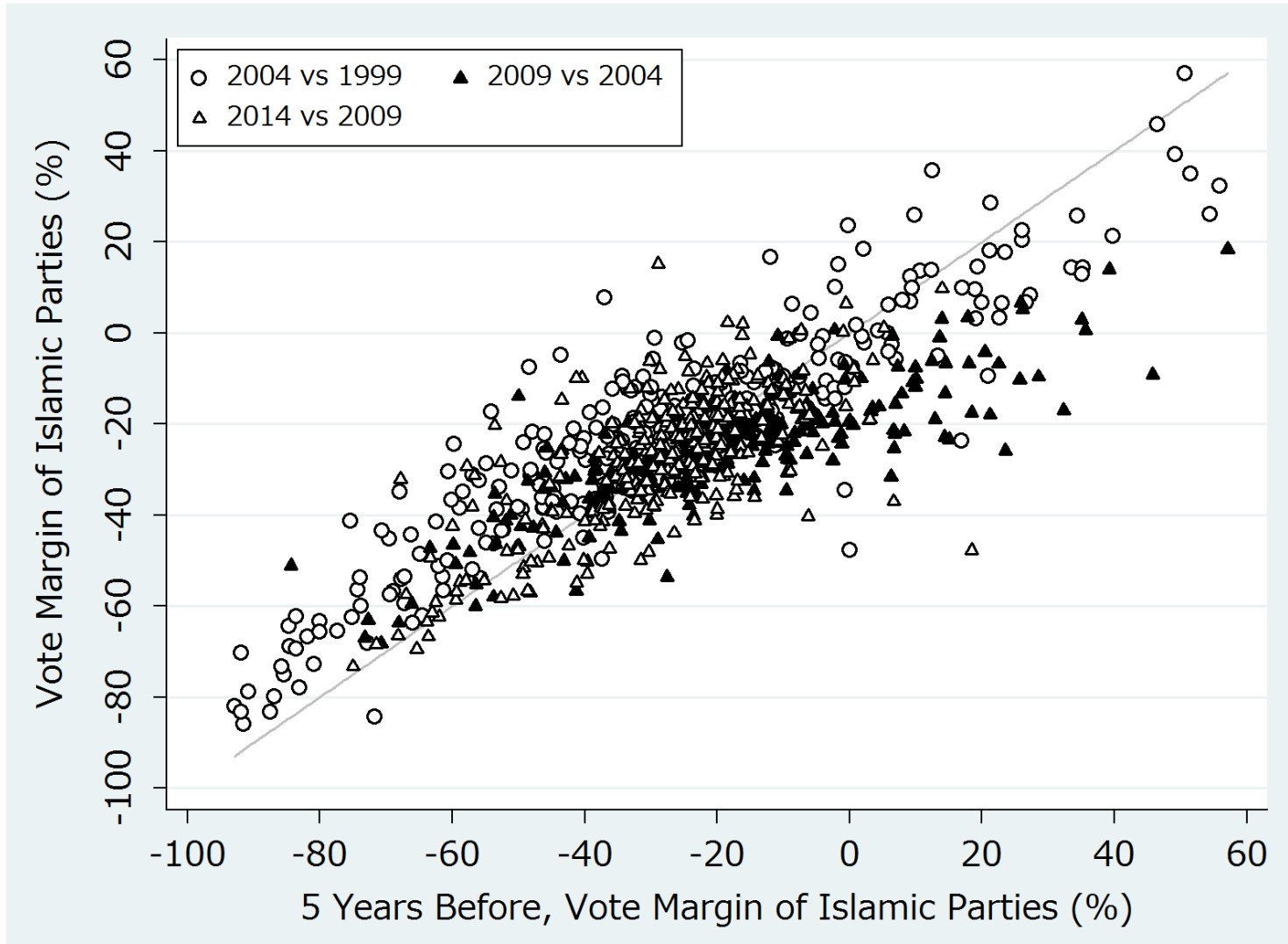

Source: Authors' calculation based on KPU data. 
Figure 2. Vote Share of Islamic Parties (1999-2014)

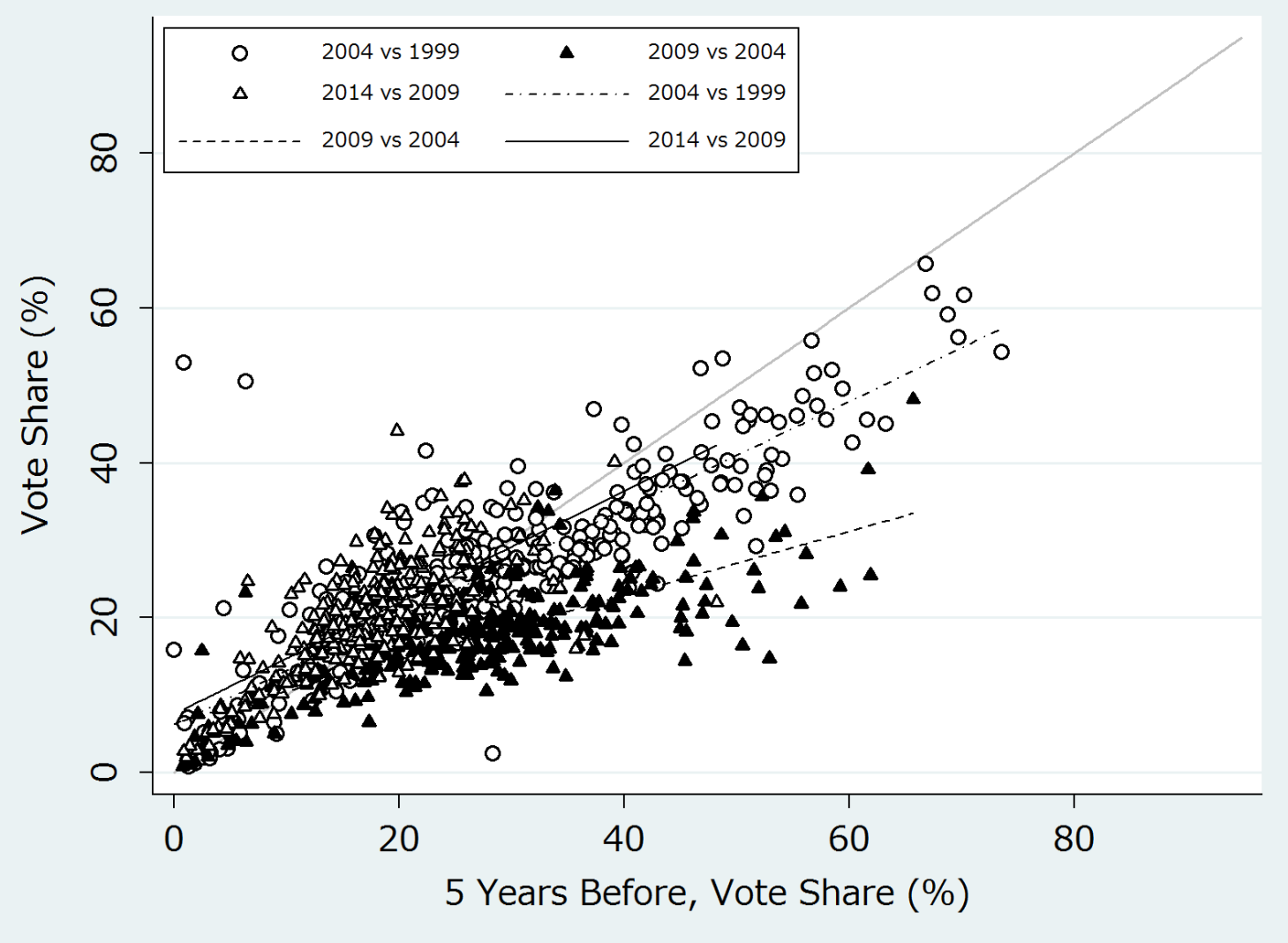

Source: Authors' calculation based on KPU data. 
Figure 3. Vote Share of Secular Parties (1999-2014)

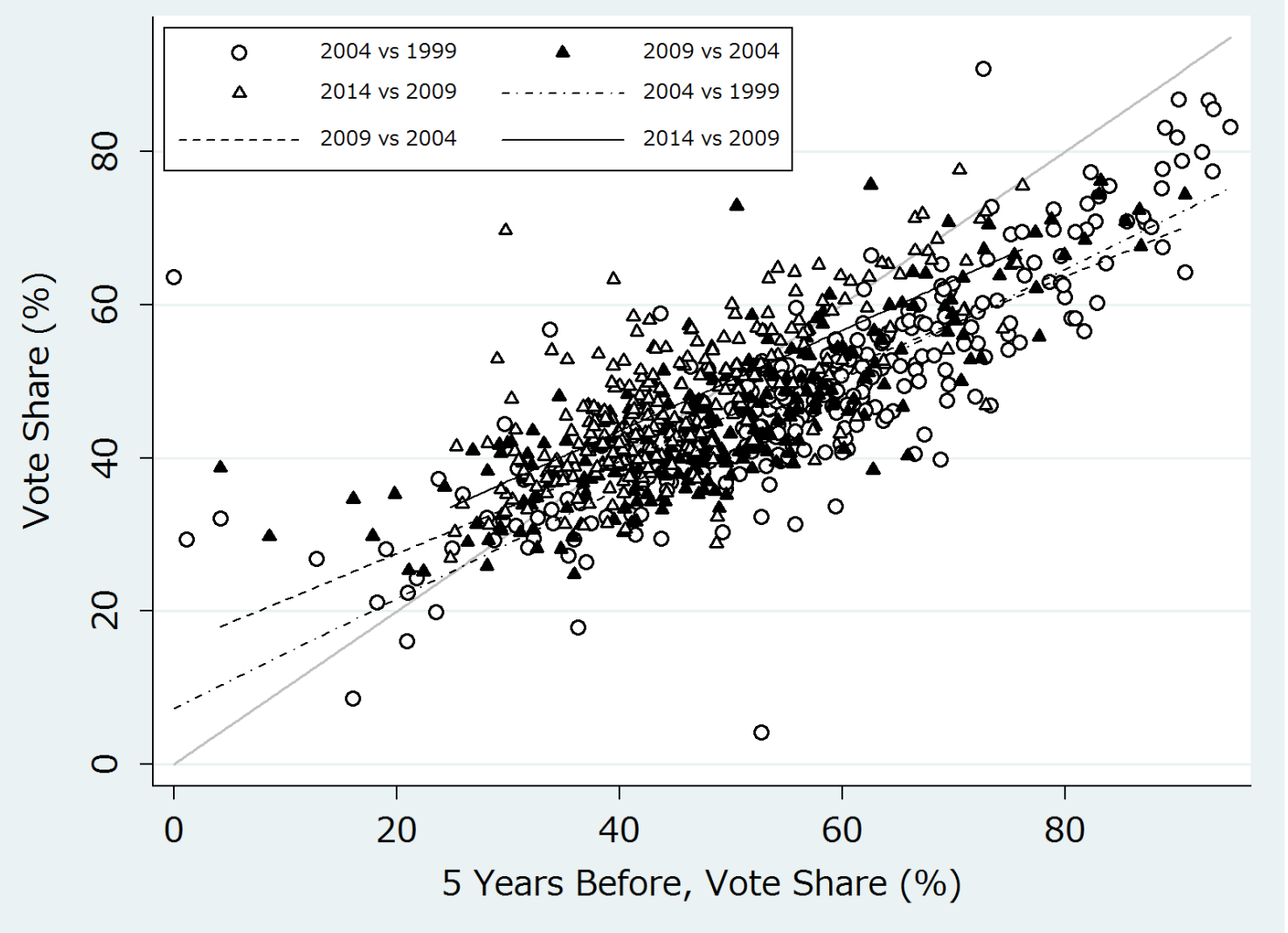

Source: Authors' calculation based on KPU data. 
Figure 4. Change in Vote Share of Islamic Parties and Golput (2004 - 2009)

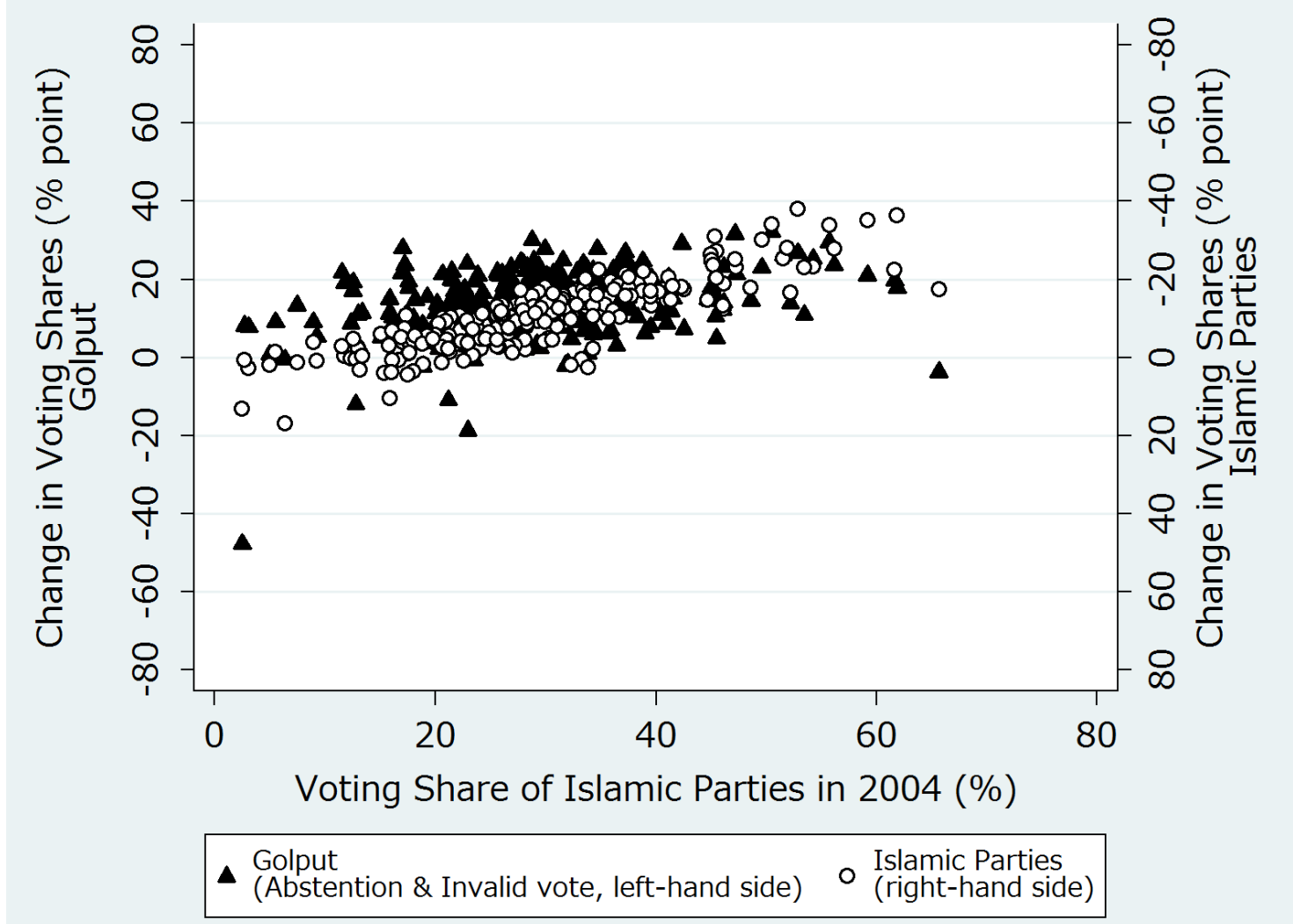

Source: Authors' calculation based on KPU data. 
Figure 5. Change in Vote Share of Secular Parties and Golput (2004 - 2009)

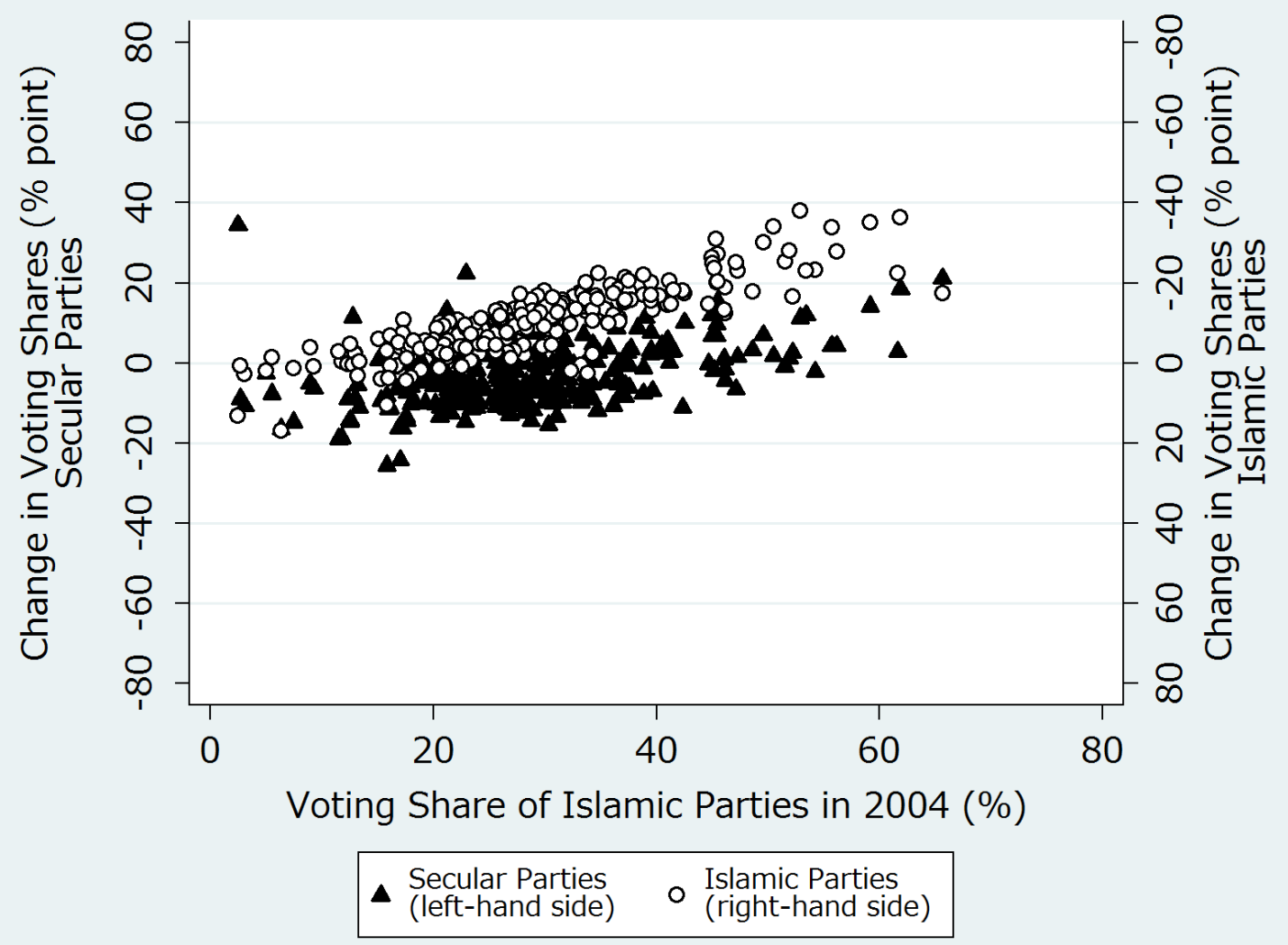

Source: Authors' calculation based on KPU data. 
Figure 6. Vote Margin of Islamic Parties and Population Share of Muslims (1999 - 2009)

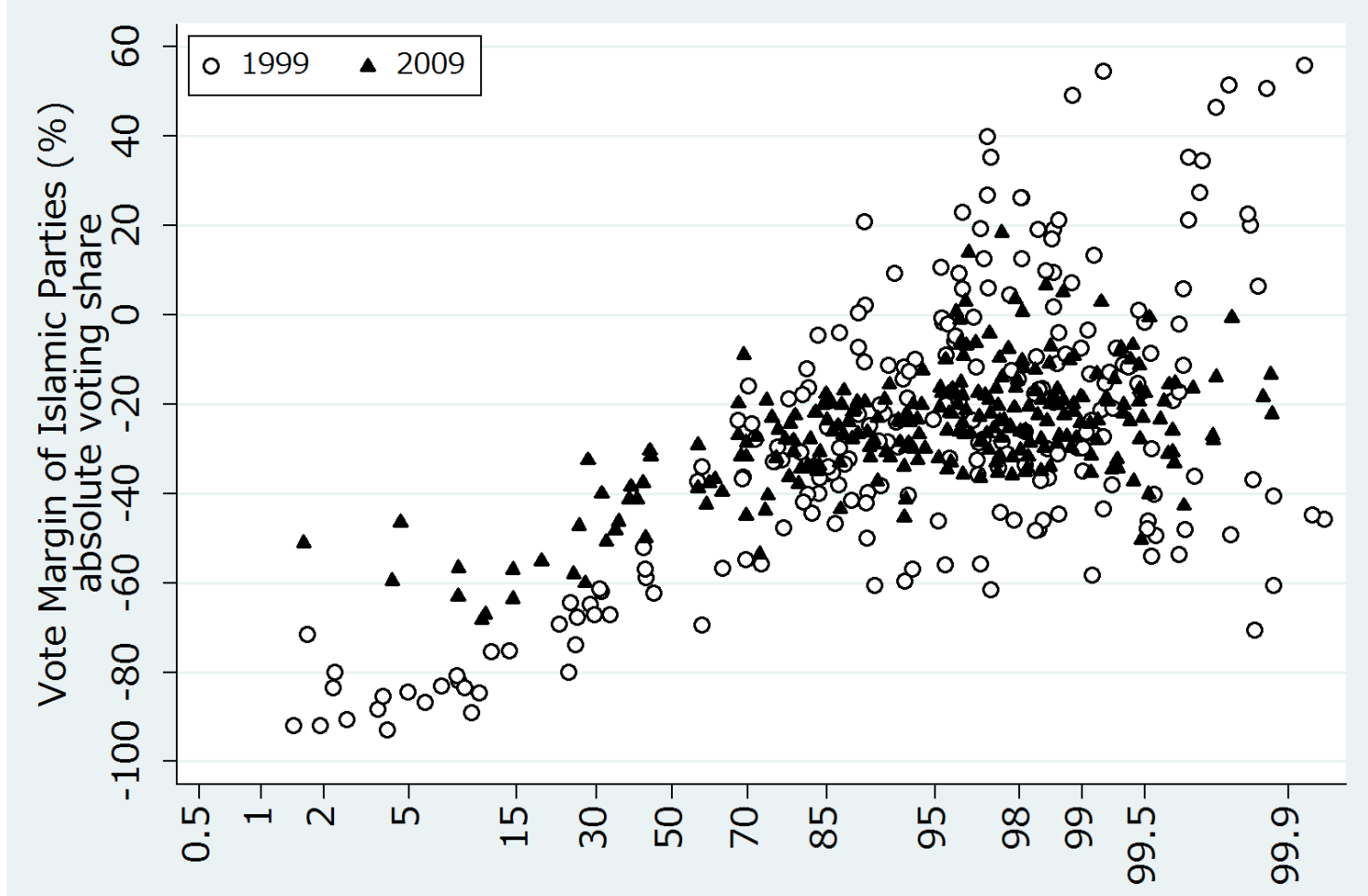

Population Share of Muslims (\%, in Log Odds Ratio)

Source: Authors' calculation based on KPU data and BPS (2001, 2011). 
Figure7. Vote Margin of Islamic Parties and Number of Masjid per 1000 people (1999-2009)

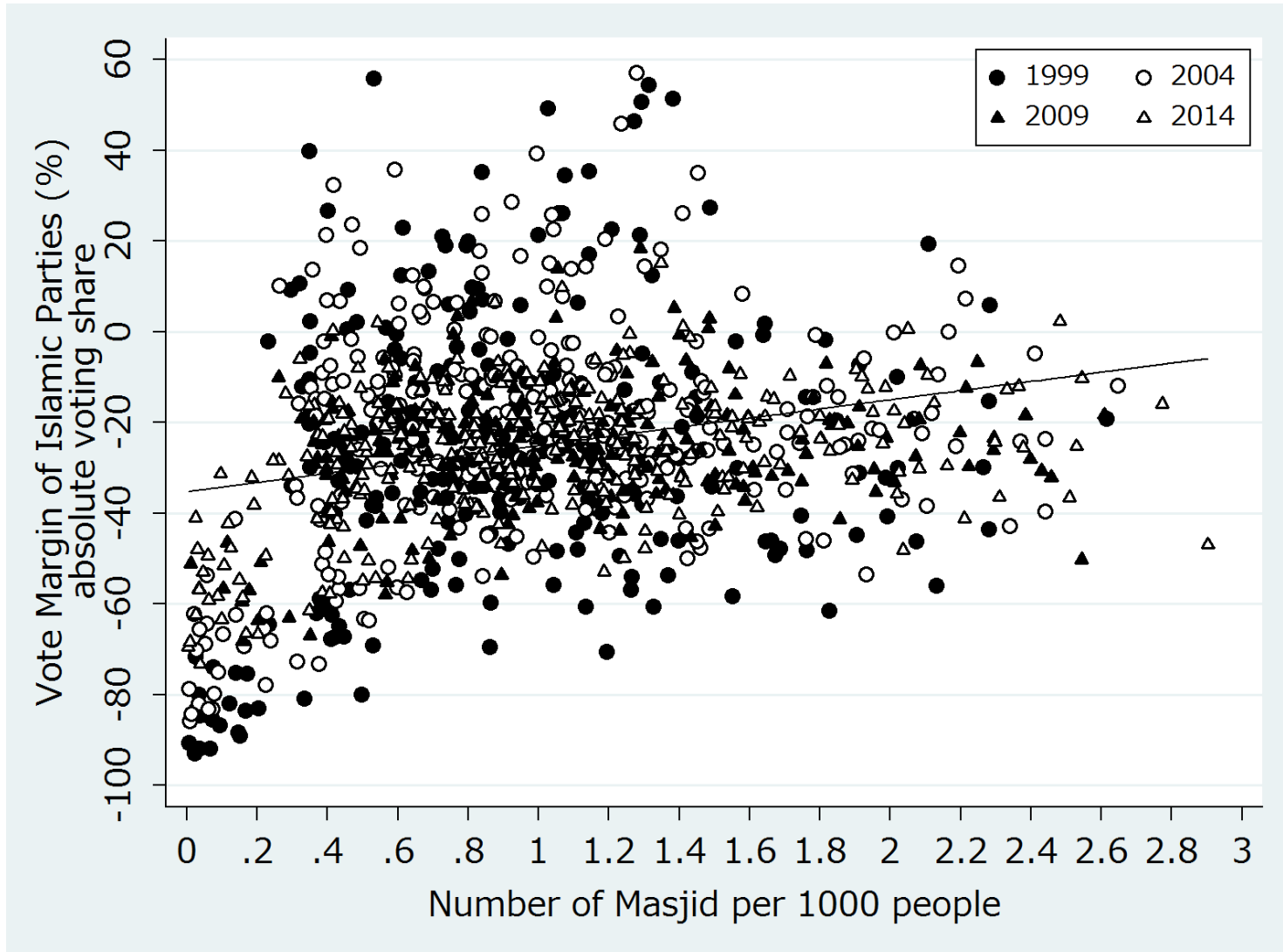

Source: Authors' calculation based on KPU data and Podes. 
Figure 8. Vote Margin of Ruling Parties and Growth Rate of Per Capita GDP (2004-2014)

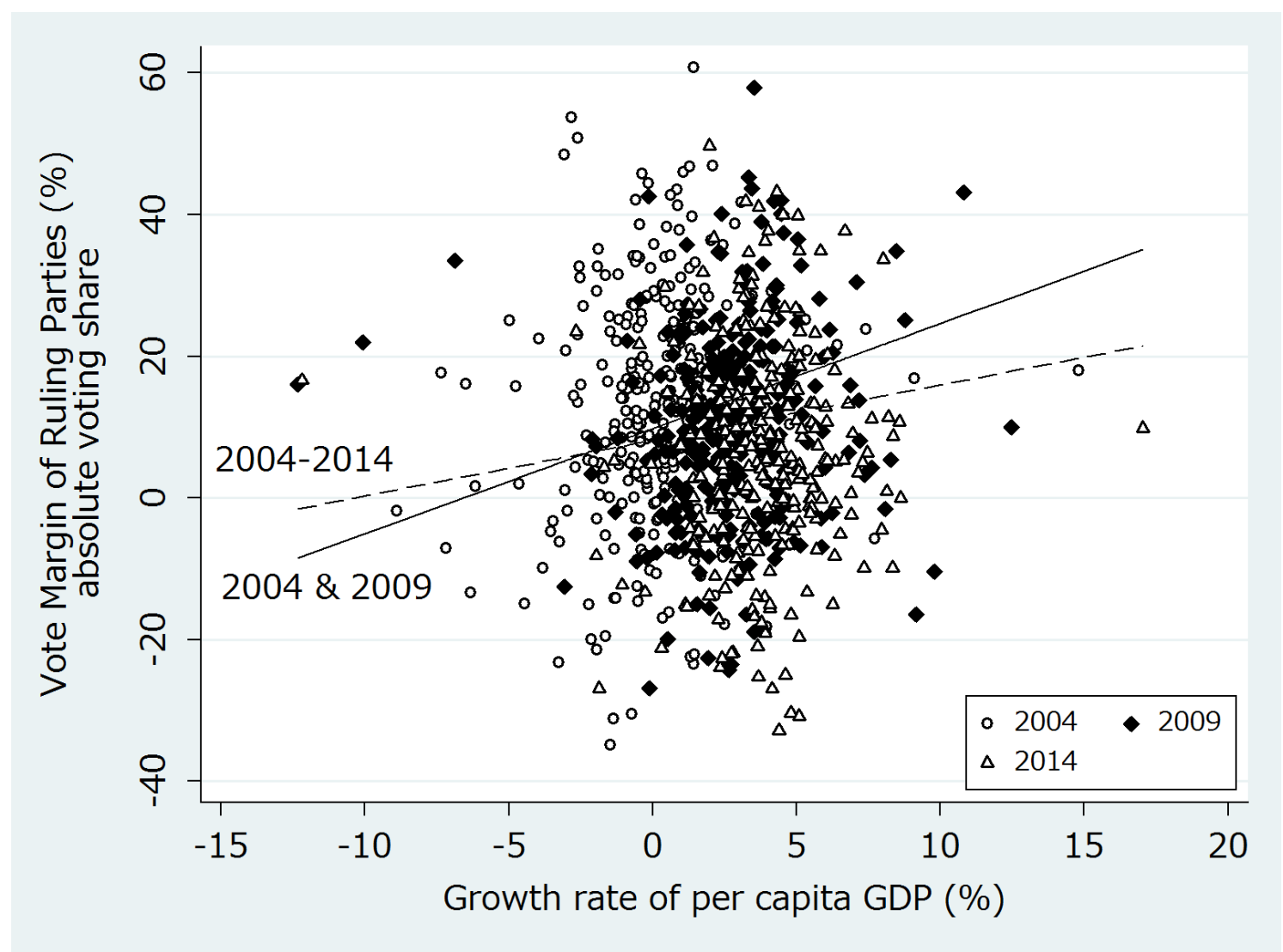

Source: Authors' calculation based on KPU data and BPS (2003, 2007, 2013). 
Table 1. Election Results after Democratization

\begin{tabular}{|c|c|c|c|c|c|c|c|c|}
\hline & \multicolumn{2}{|c|}{$1999-2004$} & \multicolumn{2}{|c|}{ 2004-2009 } & \multicolumn{2}{|c|}{$2009-2014$} & \multicolumn{2}{|c|}{ 2014-2019 } \\
\hline & Vote Share & Seat Share & Vote Share & Seat Share & Vote Share & Seat Share & Vote Share & Seat Share \\
\hline$\overline{P D I P}$ & $33.7 \%$ & $30.6 \%$ & $18.5 \%$ & $19.8 \%$ & $14.0 \%$ & $16.8 \%$ & $19.0 \%$ & $19.5 \%$ \\
\hline Golkar & $22.4 \%$ & $24.0 \%$ & $21.6 \%$ & $23.1 \%$ & $14.5 \%$ & $18.9 \%$ & $14.8 \%$ & $16.3 \%$ \\
\hline PD & --- & -- & $7.5 \%$ & $10.2 \%$ & $20.9 \%$ & $26.4 \%$ & $10.2 \%$ & $10.9 \%$ \\
\hline Gerindra & --- & --- & --- & --- & $4.5 \%$ & $4.6 \%$ & $11.8 \%$ & $13.0 \%$ \\
\hline Hanura & --- & --- & --- & --- & $3.8 \%$ & $3.0 \%$ & $5.3 \%$ & $2.9 \%$ \\
\hline NasDem & --- & --- & --- & --- & --- & --- & $6.7 \%$ & $6.3 \%$ \\
\hline PPP & $7.1 \%$ & $6.8 \%$ & $8.2 \%$ & $10.6 \%$ & $5.3 \%$ & $6.8 \%$ & $6.5 \%$ & $7.0 \%$ \\
\hline PKB & $12.6 \%$ & $10.2 \%$ & $10.6 \%$ & $9.5 \%$ & $7.9 \%$ & $5.0 \%$ & $9.0 \%$ & $8.4 \%$ \\
\hline PAN & $7.1 \%$ & $6.8 \%$ & $6.4 \%$ & $9.6 \%$ & $6.0 \%$ & $8.2 \%$ & $7.6 \%$ & $8.8 \%$ \\
\hline PKS & $1.4 \%$ & $1.4 \%$ & $7.3 \%$ & $8.2 \%$ & $7.9 \%$ & $10.2 \%$ & $6.8 \%$ & $7.1 \%$ \\
\hline Others & $9.1 \%$ & $8.4 \%$ & $16.1 \%$ & $9.1 \%$ & $15.6 \%$ & $0.0 \%$ & $0.0 \%$ & $0.0 \%$ \\
\hline Secular Parties Total & $62.4 \%$ & $62.8 \%$ & $61.7 \%$ & $57.6 \%$ & $70.8 \%$ & $69.8 \%$ & $68.6 \%$ & $68.8 \%$ \\
\hline Islamic Parties Total & $37.6 \%$ & $37.2 \%$ & $38.3 \%$ & $42.6 \%$ & $29.2 \%$ & $30.2 \%$ & $31.4 \%$ & $31.3 \%$ \\
\hline $\begin{array}{l}\text { Effective Number of Parties } \\
\text { (Electoral and Legislative) }\end{array}$ & 5.1 & 4.7 & 8.6 & 7.1 & 6.1 & 6.2 & 8.9 & 8.2 \\
\hline Volatility & & & & & & & & \\
\hline Total Volatility & & & & 23.0 & & 26.6 & & 26.3 \\
\hline Total Volatility Without Others & & & & 20.1 & & 20.7 & & 19.0 \\
\hline Block Volatility & & & & 1.5 & & 9.2 & & 2.0 \\
\hline Within Block Volatility (TV-BV) & & & & 21.5 & & 17.4 & & 24.4 \\
\hline Share of WBV in TV & & & & $93.7 \%$ & & $65.4 \%$ & & $92.5 \%$ \\
\hline
\end{tabular}

Note: The figures in italics indicate the first winning party in each election.

Source: Authors' calculation based on KPU data. 
Table 2. Summary Statistics: Religious Cleavage Voting (1999-2014)

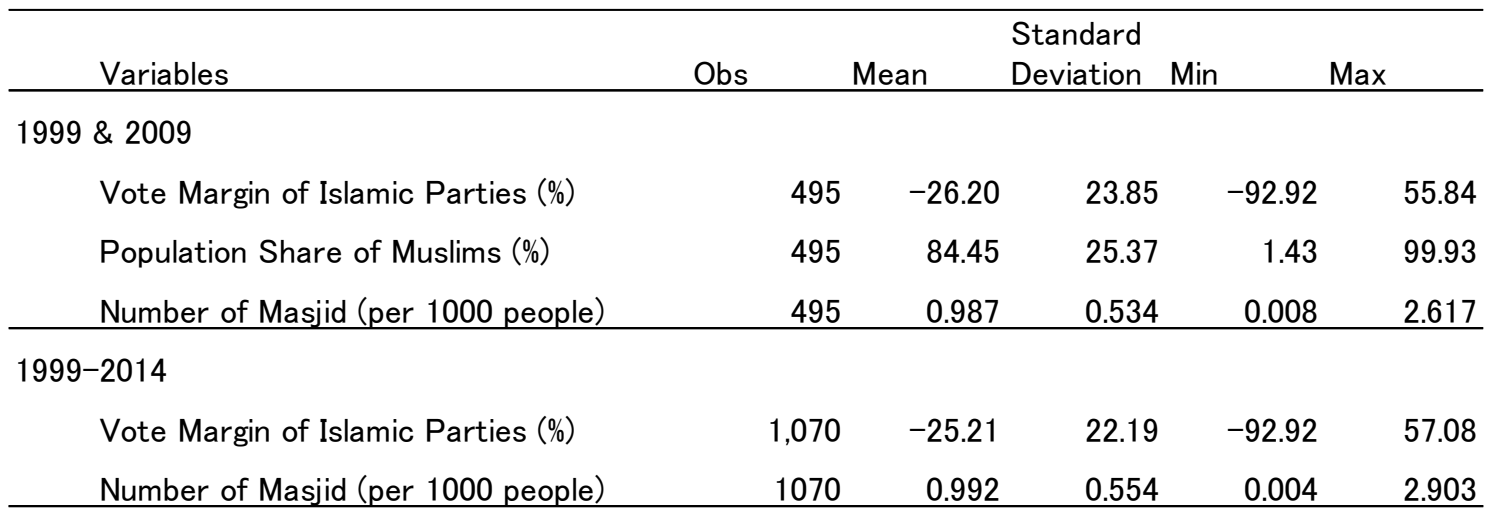

Source: Authors' calculation based on KPU data, BPS $(2001,2011)$ and Podes data. 
Table 3. Summary Statistics: Religious Cleavage Voting (1999-2014)

\begin{tabular}{|c|c|c|c|c|c|c|c|}
\hline & \multirow{2}{*}{$\begin{array}{c}\text { Islamic Parties' Share } \\
\text { in } 2004 \\
\end{array}$} & \multicolumn{2}{|c|}{$\Delta$ Islam } & \multicolumn{2}{|c|}{$\Delta$ Golput } & \multicolumn{2}{|c|}{$\Delta$ Secular } \\
\hline & & 2004-2009 & 2009-2014 & 2004-2009 & 2009-2014 & 2004-2009 & 2009-2014 \\
\hline $1 \mathrm{st}$ & 15.2 & -1.9 & 2.8 & 9.9 & -4.9 & -8.0 & 2.1 \\
\hline $2 n d$ & 23.5 & -6.7 & 3.5 & 11.3 & -2.7 & -4.6 & -0.8 \\
\hline $3 r d$ & 27.8 & -10.1 & 2.9 & 15.4 & -4.8 & -5.3 & 1.9 \\
\hline 4 th & 33.4 & -12.5 & 2.0 & 15.3 & -3.8 & -2.8 & 1.8 \\
\hline 5 th & 45.8 & -21.5 & 1.7 & 17.9 & -7.1 & 3.6 & 5.3 \\
\hline
\end{tabular}

Source: Authors' calculation based on KPU data. 
Table 4. Results: Religious Cleavage Voting (1999-2014)

\begin{tabular}{lccccc}
\hline & \multicolumn{3}{c}{$1999 \& 2009$} & \multicolumn{3}{c}{$1999-2014$} \\
& $(1)$ & $(2)$ & $(3)$ & $(4)$ & $(5)$ \\
\hline Population Share & $0.617^{* * *}$ & $2.377^{* *}$ & $2.082^{* *}$ & & \\
$\quad$ of Muslims (\%) & $(0.032)$ & $(0.993)$ & $(0.970)$ & & \\
Number of Masjid & & & $41.517^{* * *}$ & $10.224^{* * *}$ & $19.578^{* * *}$ \\
(per 1000 people) & & & $(11.717)$ & $(1.187)$ & $(5.736)$ \\
\hline Year Dummy & Yes & Yes & Yes & Yes & Yes \\
Regional Dummy & No & Yes & Yes & No & Yes \\
F statistics for fixed effect & & $1.705^{* * *}$ & $1.729^{* * *}$ & & $8.223^{* * *}$ \\
\hline Adjusted R & 0.427 & 0.593 & 0.615 & 0.070 & 0.689 \\
Sample Size & 495 & 495 & 495 & 1,070 & 1,070 \\
\hline
\end{tabular}

Note: Huber robust standard errors are in parenthesis. * significant at $10 \%, * *$ significant at $5 \%$, and $* * *$ significant at $1 \%$.

Source: Authors' calculation based on KPU data, BPS $(2001,2011)$ and Podes data. 
Table 5. Summary Statistics: Vote Margin of Ruling Parties and Growth Rate of Per Capita GDP (2004-2014)

\begin{tabular}{|c|c|c|c|c|c|}
\hline Year & Obs & Mean & $\begin{array}{l}\text { Standard } \\
\text { Deviation }\end{array}$ & Min & Max \\
\hline \multicolumn{6}{|l|}{ Sample 1} \\
\hline \multicolumn{6}{|c|}{ Vote Margin of Ruling Parties (\%) } \\
\hline 2004 & 283 & 12.83 & 16.80 & -34.86 & 60.78 \\
\hline 2009 & 265 & 10.66 & 14.35 & -26.86 & 57.94 \\
\hline 2014 & 292 & 6.22 & 14.79 & -32.86 & 49.71 \\
\hline \multicolumn{6}{|c|}{ Growth Rate of per capita GDP (\%) } \\
\hline 2004 & 283 & -0.26 & 4.57 & -47.39 & 19.43 \\
\hline 2009 & 265 & 3.00 & 3.86 & -12.34 & 46.81 \\
\hline 2014 & 292 & 3.77 & 2.21 & -12.19 & 17.04 \\
\hline
\end{tabular}

Sample 2

Vote Margin of Ruling Parties (\%)

$\begin{array}{lrrrrr}2004 & 278 & 13.03 & 16.82 & -34.86 & 60.78 \\ 2009 & 263 & 10.55 & 14.29 & -26.86 & 57.94 \\ 2014 & 292 & 6.22 & 14.79 & -32.86 & 49.71\end{array}$

Growth Rate of per capita GDP (\%)

\begin{tabular}{llllrl}
2004 & 278 & 0.09 & 2.42 & -8.91 & 14.81 \\
2009 & 263 & 2.77 & 2.55 & -12.34 & 12.48 \\
2014 & 292 & 3.77 & 2.21 & -12.19 & 17.04 \\
\hline
\end{tabular}

Source: Authors' calculation based on KPU data and BPS (2003, 2007, 2013). 
Table 6. Results: Economic Voting

\begin{tabular}{|c|c|c|c|c|c|c|c|c|}
\hline & \multicolumn{4}{|c|}{ Sample 1} & \multicolumn{4}{|c|}{ Sample 2} \\
\hline & \multicolumn{2}{|c|}{ 2004-2009 } & \multicolumn{2}{|c|}{ 2004-2014 } & \multicolumn{2}{|c|}{ 2004-2009 } & \multicolumn{2}{|c|}{ 2004-2014 } \\
\hline & (1) & (2) & (3) & (4) & (5) & (6) & (7) & (8) \\
\hline $\begin{array}{l}\text { Growth Rate } \\
\text { of per capita GDP }\end{array}$ & $\begin{array}{c}0.502^{* * *} \\
(0.149)\end{array}$ & $\begin{array}{c}0.609 \\
(0.336)\end{array}$ & $\begin{array}{c}0.444^{* * *} \\
(0.130)\end{array}$ & $\begin{array}{c}0.480^{* * *} \\
(0.178)\end{array}$ & $\begin{array}{c}0.733^{* * *} \\
(0.280)\end{array}$ & $\begin{array}{c}1.484^{* * *} \\
(0.481)\end{array}$ & $\begin{array}{c}0.526 \\
(0.222)\end{array}$ & $\begin{array}{c}0.783^{\text {*** }} \\
(0.293)\end{array}$ \\
\hline Year 2004 & $\begin{array}{c}3.803^{* * *} \\
(1.389)\end{array}$ & $\begin{array}{r}2.914 \\
(1.550)\end{array}$ & $\begin{array}{c}8.402^{* * *} \\
(1.563)\end{array}$ & $\begin{array}{l}8.488^{* * *} \\
(1.409)\end{array}$ & $\begin{array}{c}4.450^{* * *} \\
(1.496)\end{array}$ & $\begin{array}{c}5.560 \\
(1.956)\end{array}$ & $\begin{array}{c}8.755^{* * *} \\
(1.563)\end{array}$ & $\begin{array}{c}9.710^{* * *} \\
(1.688)\end{array}$ \\
\hline Year 2009 & & & $\begin{array}{c}4.787^{* * *} \\
(1.245)\end{array}$ & $\begin{array}{c}4.897^{* * *} \\
(1.069)\end{array}$ & & & $\begin{array}{r}4.858 \\
(1.270)\end{array}$ & $5^{5.141}{ }^{\text {(1.0* }}$ \\
\hline Constant & $\begin{array}{l}9.154^{* * *} \\
(0.962)\end{array}$ & $\begin{array}{l}9.472^{* * *} \\
(1.264)\end{array}$ & $\begin{array}{l}4.540^{* * *} \\
(1.018)\end{array}$ & $\begin{array}{l}4.399^{* * *} \\
(1.044)\end{array}$ & $\begin{array}{l}8.518^{* * *} \\
(1.163)\end{array}$ & $\begin{array}{l}6.903^{* * *} \\
(1.684)\end{array}$ & $\begin{array}{l}4.231^{* * *} \\
(1.249)\end{array}$ & $\begin{array}{l}3.252^{* *} \\
(1.391)\end{array}$ \\
\hline Regional Dummy & No & Yes & No & Yes & No & Yes & No & Yes \\
\hline$F$ statistics for fixed effect & & $1.774^{* * *}$ & & $1.814^{* * *}$ & & $1.921^{* * *}$ & & $1.825^{* * *}$ \\
\hline Adjusted $\mathrm{R}^{2}$ & 0.023 & 0.308 & 0.043 & 0.253 & 0.020 & 0.344 & 0.040 & 0.254 \\
\hline Sample Size & 548 & 548 & 840 & 840 & 541 & 541 & 833 & 833 \\
\hline
\end{tabular}

Note: Huber robust standard errors are in parenthesis. * significant at $10 \%, * *$ significant at $5 \%$, and $* * *$ significant at $1 \%$.

Source: Authors' calculation based on KPU data and BPS (2003, 2007, 2013). 
Table A1. Islamic and Secular Parties

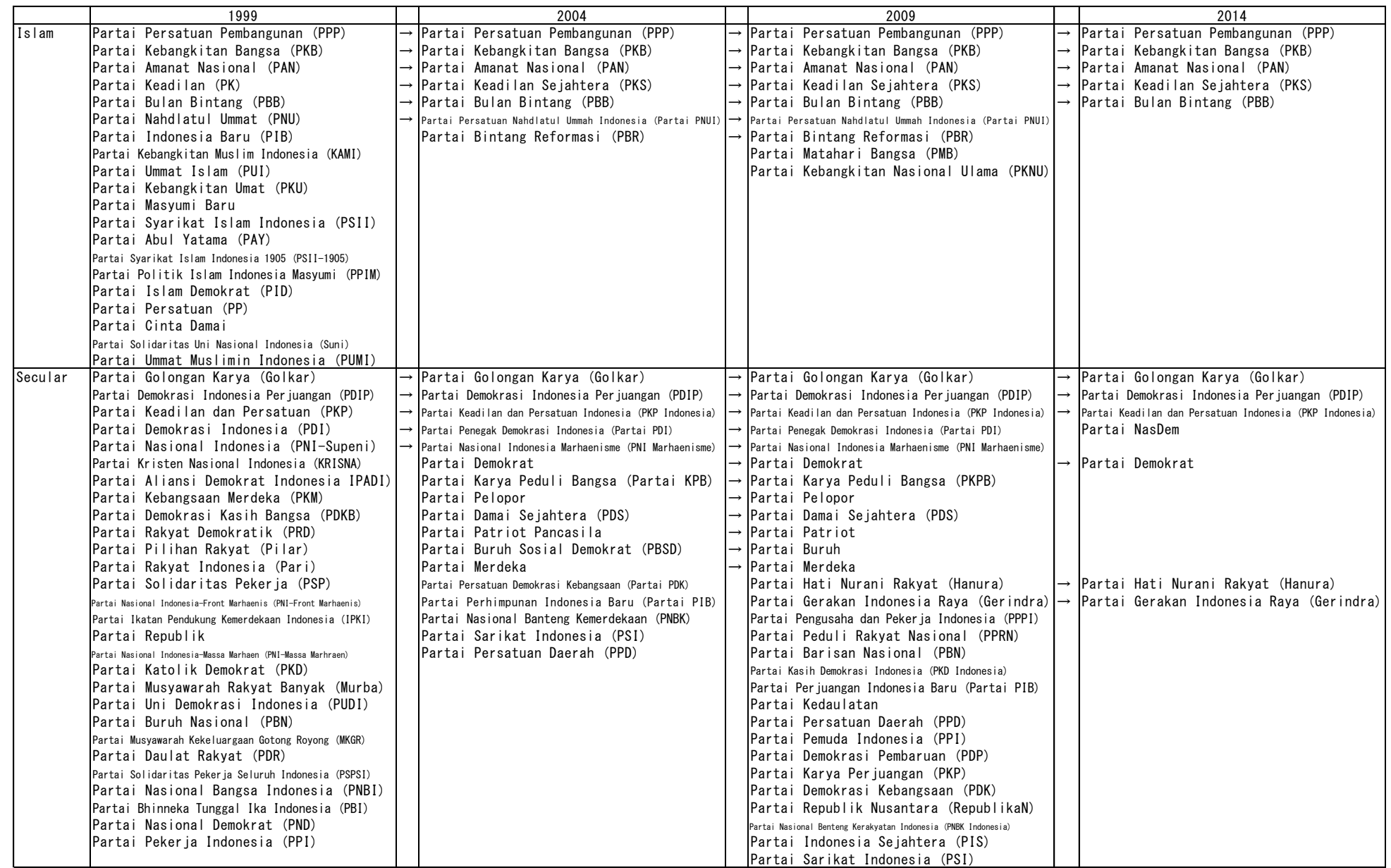

Note: Arrows indicate the same party; however, parties which were established through mergers of small parties are excluded. Source: Authors. 
Table A2. Ruling Parties

\begin{tabular}{|c|c|c|c|c|c|c|}
\hline President & B.J. Habibie & Abdurrahman Wahid & Megawati Sukarnoputri & $\begin{array}{l}\text { 1st Susilo Bambang } \\
\text { Yudhoyono }\end{array}$ & $\begin{array}{c}\text { 2nd Susilo Bambang } \\
\text { Yudhoyono }\end{array}$ & Joko Widodo \\
\hline Period & $\begin{array}{l}20 \text { May } 1998- \\
19 \text { Oct. } 1999\end{array}$ & $\begin{array}{l}20 \text { Oct. } 1999- \\
22 \text { July } 2001\end{array}$ & $\begin{array}{l}23 \text { July } 2001- \\
19 \text { Oct. } 2004\end{array}$ & $\begin{array}{l}20 \text { Oct. } 2004- \\
19 \text { Oct. } 2009\end{array}$ & $\begin{array}{l}20 \text { Oct. } 2009- \\
19 \text { Oct. } 2014\end{array}$ & $\begin{array}{r}20 \text { Oct. } 2014- \\
19 \text { Oct. } 2019\end{array}$ \\
\hline \multicolumn{7}{|l|}{ Parliamentary Seats of Ruling Parties } \\
\hline$\%$ of a Ruling Party* & $65.0 \%$ & $10.2 \%$ & $30.6 \%$ & $10.2 \%$ & $26.8 \%$ & $19.5 \%$ \\
\hline$\%$ of President's* \& Vice-President's** Parties & --- & $40.8 \%$ & $42.2 \%$ & $33.3 \%$ & $26.8 \%$ & $19.5 \%$ \\
\hline$\%$ of Ruling Coalition Parties ${ }^{1)}$ & $97.8 \%$ & $94.8 \%$ & $83.2 \%$ & $63.8 \%$ & $75.5 \%$ & $43.9 \%$ \\
\hline Number of Coalition Parties & 2 Parties \& 1 Faction & 7 Parties \& 1 Faction & 5 Parties and 1 Faction & 7 Parties & 6 Parties & 5 Parties \\
\hline \multirow[t]{7}{*}{ Compositions of Coalition Parties } & Golkar* & PKB* & PDIP* & $\mathrm{PD}^{*}$ & PD* & PDIP* \\
\hline & PPP & PDIP** & PPP** & Golkar** & PKS & PKB \\
\hline & Military/Police & Golkar & PBB & PKS & PAN & NasDem \\
\hline & & PAN & PAN & PAN & PPP & Hanura \\
\hline & & PPP & Golkar & PBB & PKB & PPP \\
\hline & & $\mathrm{PBB}$ & Military/Police & PKPI & Golkar & $(\mathrm{PKPI})^{2)}$ \\
\hline & & $\begin{array}{c}\text { PK } \\
\text { Military/Police }\end{array}$ & & PPP & & \\
\hline
\end{tabular}

Notes: (1) From the Habibie to the Megawati administrations, the percentages of the ruling coalition parties' seats have been calculated, including those of the military/police faction since the said faction participated in these administrations.

(2) PKPI, which participated in Joko Widodo's coalition in the 2014 presidential election, failed to acquire parliamentary seats since its vote share didn't surpass the parliamentary threshold of $3.5 \%$ in the parliamentary elections.

(3) * indicates a president's party, and ** indicates a vice-President's party.

Source: Authors. 